\title{
Biosynthesis of silver nanoparticles by Enterobacter sp. and their antifungal activity against the phytopathogenic fungus Fusarium oxysporum f. sp. lycopersici
}

\author{
Mohamed M. El-Zahed ${ }^{1 *}$, Mahmoud M. Nour El-Dein ${ }^{1}$, Mohamed I. Abou-Dobara ${ }^{1}$ and Zakaria A. M. Baka ${ }^{1}$ \\ ${ }^{1}$ Department of Botany and Microbiology, Faculty of Science, Damietta University, New Damietta, PO 34517 , \\ Egypt.
}

Received: 5 May 2017 /Accepted: 16 July 2017

*Corresponding author: Mohamed.marzouq90@gmail.com or Mohamed.marzouq91@ du.edu.eg

\begin{abstract}
This study was concerned with the isolation of bacterial strains from different water sources. Among these strains; Enterobacter sp. exhibited extracellularly biosynthesized silver nanoparticles with good monodispersity. Enterobacter sp. has produced extremely stable nanoparticles within $72 \mathrm{hrs}$ at $35^{\circ} \mathrm{C}$ in dark conditions. These nanoparticles are characterized by UV-vis spectrophotometer, transmission electron microscopy, Zeta potential analyzer, and size distribution by volume. Enterobacter sp. synthesized 9.45-17.15 nm sized spherical shaped silver nanoparticles. The presence and binding of stabilized proteins with nanoparticles were confirmed by the zeta size distribution by volume. Our study demonstrates that silver nanoparticles are potent inhibitors of the plant pathogenic fungus, Fusarium oxysporum f. sp. lycopersici.

Keywords: nanoparticle, silver, Enterobacter sp., antifungal.
\end{abstract}

\section{Introduction}

Nanobiotechnology is a branch of nanotechnology at which biological systems as microorganisms and plant extracts are used to generate nanoparticles (NPs) with specific functions that are featured by safety, non-toxicity, and ecofriendly processing (Ahmad et al., 2005; Boisselier and Astruc, 2009; Sharma et al., 2012; Kafshgari et al., 2015). Particles that are created with a size range of 1-100 nanometers, the materials' chemical, physical, mechanical, electronic, thermal, electrical, magnetic, dielectric, optical, and biological properties change from those at larger scales (Morais et al., 2014). Among biological systems, bacteria are more advantageous because of its rapid growth and high efficiency in NPs biosynthesis as biofactors (Abbaszadegan et al., 2015). The supernatant broth culture of different bacterial strains is recorded as a fast bioreactor for NPs biosynthesis (Shahverdi et al., 2007).

The bacterial extracellular biosynthesis method has a great deal of interest due to its simplicity and 
lesser time consumption in contrast to intracellular biosynthesis (Balakumarana et al., 2016). The shape and size of extracellular biosynthesis can also be controlled by different factors such as metal ions concentration, temperature, $\mathrm{pH}$ (Sathishkumar et al., 2010; Krishnaraj et al., 2012). Extracellular biosynthesis of NPs can be achieved by the reduction of metal ions in a solution by the soluble secreted enzymes then it is obvious to find NPs extracellular (He et al., 2007). Because of the previous advances, the bacterial extracellular biosynthesis method is often considered as the best resource for higher productivity of NPs (Shanmugaiah et al., 2015).

The extracellular biosynthesis of silver nanoparticles (AgNPs) has been reported using varieties of bacteria such as Escherichia coli, Pseudomonas aeruginosa, Lactobacillus strains, Morganella sp. and others as bionanofactories (Lengke and Southam, 2006; Parikh et al., 2008). Pediococcus pentosaceus and Enterococcus faecium were found to synthesize AgNPs (Sintubin et al., 2009). The antifungal activity of AgNPs against Fusarium oxysporum f. sp. lycopersici was observed by Dar et al. (2013) and Devi and Joshi (2012). Silver NPs form complexes with bases contained in DNA and is a potent inhibitor of fungal DNases (Devi and Bhimba, 2014). It has been proposed that silver ions interact strongly with the thiol (-SH) group of membrane bound proteins or the lipid bilayer and that it destabilizes the membrane, causing ion leakage and cell rupture (Matsumura et al., 2003). As a part of our continuing study to isolate the bacterial strain with the ability to biosynthesize AgNPs with efficient biological properties, water microbes were selected. Water bacteria are relatively unexplored as a resource of bioreductants for the extracellular biosynthesis of AgNPs. This study was concerned with the isolation of bacterial strains from different localities in Damietta Governorate, Egypt with the better extracellular biosynthesis of new functional AgNPs and showing their antifungal activity Fusarium oxysporum f. sp. lycopersici.

\section{Materials and methods}

\section{Chemicals}

Silver nitrate was purchased from Panreac Quimica S.L.U, Barcelona, Spain.

\section{Collection of water samples}

Twenty water samples were collected from different localities; The River Nile, Ezbet ELBorg canal, Ezbet EL-Borg sewage treatment station and Masraf Sittah in Damietta Governorate, Egypt. These water samples were taken from places along water source and different depths in sterile glass bottles. All samples were immediately transported to microbiology laboratory for isolation of bacteria.

\section{Isolation of water bacteria}

Samples of water were mixed well for each place separately under aseptic conditions. The bacteria were isolated by plating dilutions. Petri dishes containing nutrient agar (NA) medium were mixed well with $0.1 \mathrm{~mL}$ of the water sample, and incubated at $37^{\circ} \mathrm{C}$ for $24 \mathrm{hrs}$. After the incubation period, the developed single colonies of bacteria which vary in shape and color were picked up and purified. The purified bacterial isolates were regularly subcultured and stored on NA slants at $4^{\circ} \mathrm{C}$ for further use.

\section{Identification of the isolated water bacteria}

The purified bacterial isolates were stained with Gram and endospore stains and identified on the basis of colony characters; size, form, pigment production, elevation, surface, edge, color, opacity and physiological properties according to Bergey's Manual of Systematic Bacteriology (Garrity et al., 2006).

\section{Screening of water bacteria for extracellular biosynthesis of silver nanoparticles}

All the bacterial isolates were screened for the biosynthesis of AgNPs extracellularly. To prepare the bacterial supernatant, the isolates were grown aerobically in nitrate broth medium containing $(\mathrm{g} / \mathrm{L})$ : peptone, 5.0; meat extract, $3 ; \mathrm{KNO}_{3}, 1, \mathrm{pH}$ $7.0 \pm 0.2$ and incubated at $37^{\circ} \mathrm{C}$ for $24 \mathrm{hrs}$ at 150 rpm. After incubation, bacterial isolates were centrifuged at $4000 \mathrm{rpm}$ for $20 \mathrm{~min}$ under aseptic conditions to collect the culture supernatants. A volume of $5 \mathrm{~mL}$ of an autoclaved aqueous solution of $1 \mathrm{mM}$ silver nitrate was mixed with 50 $\mu \mathrm{L}$ of culture supernatant $(1 \% \mathrm{v} / \mathrm{v})$ in a test tube, in addition to a test tube containing $5 \mathrm{~mL}$ of silver 
nitrate solution and $50 \mu \mathrm{L}$ of the nitrate broth medium as a control. All experiments were done in triplicates. The whole samples were kept in the shaking incubator at $150 \mathrm{rpm}$ and maintained in dark conditions for 5 days at $37^{\circ} \mathrm{C}$. After the incubation period, the reduction of silver nitrate was monitored by visible color change of the solution into brown color (Shahverdi et al., 2007).

\section{S rDNA sequencing and phylogenetic analysis}

Bacterial genomic DNA was extracted by phenol/chloroform technique according to Ausubel et al. (2003). The 16S rRNA gene was amplified by using the prokaryotic universal pairs of primers (27F: 5'AGAGTTTGATCMTGGCTCAG ${ }^{3}$ ) and (1492R: 5'TACGGYTACCTTGTTACGACTT ${ }^{3}$ ') (Jiang et al., 2006). The amplified PCR product was sequenced by Macrogen, Korea using the same previous primers. BLAST (Altschul et al., 1990 and 1997) was performed for the resulting 16S rDNA sequence to match the best similarities with other related sequences in database. The best DNA sequence similarities with our $16 \mathrm{~S}$ rDNA region were obtained from NCBI GenBank and aligned using CLUSTAL Omega (Sievers et al., 2011). Unalienable regions were excluded manually and the sequences from the same species and unidentified organisms were discarded. Finally, phylogenetic tree analyses were viewed and analyzed using MEGA version 4 (Tamura et al., 2007). The neighbor-joining was performed using the maximum composite likelihood methods (Tamura and Nei, 1993). The values 20 or above were only considered and represented next to the phylogenetic tree branches with confidence levels estimated by 1000 bootstrap replicates.

\section{Characterization of biosynthesized silver nanoparticles}

Characterization of AgNPs was done through visual observation of change in color and observed using UV-vis spectrophotometer (Beckman DU40). The biosynthesized AgNPs was confirmed by sampling the reaction mixture at regular intervals and the absorption spectra was scanned at the wavelength of 370-750 $\mathrm{nm}$ using Unicam UV-vis Spectrometer UV2, USA (Chou et al., 2005). Silver nanoparticles were analyzed using transmission electron microscopy at an accelerating voltage of $200 \mathrm{kv}$ using TEM JEOL JEM-2100, Japan in Electron Microscope Unit, Mansoura University, Egypt according to the method of Wang (2000). In addition, zeta potential studies and size distribution by volume, the nanocolloidal solution stability and surface charge of nanoparticles were measured by Zeta Potential Analyzer (Model Malvern Zeta-size Nano-zs90, USA) according to the method of Hanaor et al. (2012).

\section{Antifungal activity of biosynthesized silver nanoparticles}

The antifungal activity of the biosynthesized AgNPs against Fusarium oxysporum f. sp. lycopersici, was performed. $100 \mu \mathrm{L}$ of each; AgNPs solution, the antifungal miconazole nitrate (conc.) (positive control), distilled water (negative control), $1 \mathrm{mM}$ silver nitrate (bulk salt solution) and a mixture of AgNPs solution and miconazole nitrate $(1: 1 \mathrm{v} / \mathrm{v})$ were added into separate flasks containing sterile cold melted Dox agar medium. Media were poured into sterile petri dishes in triplicates. Each plate was inoculated by a $5 \mathrm{~mm}$ disc of testing fungi grown on Dox agar medium after incubation at $30^{\circ} \mathrm{C}$ for 5 days (check???). Plates were incubated at $30^{\circ} \mathrm{C}$ for 5 to 7 days and radial growth of fungal mycelium was recorded in $\mathrm{mm}$.

\section{Results}

Screening of water bacteria for biosynthesis of silver nanoparticles

Twenty water samples were collected from Damietta Governorate. Totally, 75 bacterial strains were isolated using NA medium. These isolates were screened for their ability to biosynthesize AgNPs using visible color change of the solution into brown color. Among them, 20 bacterial strains had the ability to produce AgNPs within 72 hrs (Table 1).

Table 1:Characteristics and screening of some isolated water bacteria for the biosynthesis of silver nanoparticles. IN=Isolate number, $\mathrm{GM}=\mathrm{Gram}$ stain, $\mathrm{EF}=$ Endospore formation, $\mathrm{SOA}=$ Synthesis of AgNPs

\begin{tabular}{|c|c|c|c|c|c|c|}
\hline NO. & IN & GS & $\begin{array}{c}\text { SHAPE } \\
\text { OF } \\
\text { CELL }\end{array}$ & EF & SOA & $\begin{array}{c}\text { LOCAT } \\
\text { ION }\end{array}$ \\
\hline 1 & A1 & $\mathrm{G}+\mathrm{ve}$ & Rod & - & - & \multirow{9}{*}{ 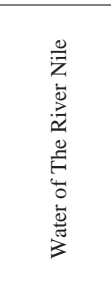 } \\
\hline 2 & A2 & $\mathrm{G}+\mathrm{ve}$ & Rod & + & - & \\
\hline 3 & A3 & $\mathrm{G}+\mathrm{ve}$ & Rod & - & - & \\
\hline 4 & A4 & $\mathrm{G}+\mathrm{ve}$ & Rod & - & - & \\
\hline 5 & A5 & $G+v e$ & Rod & + & - & \\
\hline 6 & A6 & $G+v e$ & $\begin{array}{l}\text { Cocci } \\
\text { cluster }\end{array}$ & - & - & \\
\hline 7 & A7 & $G+v e$ & Rod & - & - & \\
\hline 8 & A8 & $G+v e$ & $\begin{array}{l}\text { Cocci } \\
\text { cluster }\end{array}$ & - & - & \\
\hline 9 & A9 & $G+v e$ & Rod & - & + & \\
\hline
\end{tabular}




\begin{tabular}{|c|c|c|c|c|c|c|}
\hline 10 & A10 & $\mathrm{G}+\mathrm{ve}$ & $\begin{array}{l}\text { Cocci } \\
\text { cluster }\end{array}$ & - & - & \\
\hline 11 & A11 & $\mathrm{G}+\mathrm{ve}$ & Rod & - & - & \\
\hline 12 & A12 & $\mathrm{G}+\mathrm{ve}$ & Rod & + & - & \\
\hline 13 & A13 & $\mathrm{G}+\mathrm{ve}$ & Rod & + & - & \\
\hline 14 & A14 & $\mathrm{G}+\mathrm{ve}$ & Diplococci & - & - & \\
\hline 15 & A15 & $\mathrm{G}+\mathrm{ve}$ & Cocci & - & - & \\
\hline 16 & A16 & $\mathrm{G}+\mathrm{ve}$ & Rod & - & - & \\
\hline 17 & A17 & $\mathrm{G}+\mathrm{ve}$ & Rod & - & - & \\
\hline 18 & A18 & $\mathrm{G}+\mathrm{ve}$ & Cocci & - & - & \\
\hline 19 & A19 & $\mathrm{G}+\mathrm{ve}$ & Cocci & - & - & \\
\hline 20 & A20 & $\mathrm{G}+\mathrm{ve}$ & Diplococci & - & - & \\
\hline 21 & A21 & $\mathrm{G}+\mathrm{ve}$ & Rod & + & - & \\
\hline 22 & A22 & $\mathrm{G}+\mathrm{ve}$ & Cocci & - & - & \\
\hline 23 & $\mathrm{~A} 23$ & $\mathrm{G}+\mathrm{ve}$ & Rod & - & - & \\
\hline 24 & B1 & $\mathrm{G}+\mathrm{ve}$ & Rod & - & - & \multirow{12}{*}{ 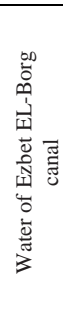 } \\
\hline 25 & B2 & G -ve & Rod & - & - & \\
\hline 26 & B3 & $\mathrm{G}+\mathrm{ve}$ & Rod & + & - & \\
\hline 27 & B4 & $G+v e$ & Rod & + & - & \\
\hline 28 & B5 & $\mathrm{G}+\mathrm{ve}$ & Rod & + & - & \\
\hline 29 & B6 & $\mathrm{G}+\mathrm{ve}$ & Rod & + & - & \\
\hline 30 & B7 & G -ve & Rod & - & - & \\
\hline 31 & B8 & $\mathrm{G}+\mathrm{ve}$ & Rod & - & - & \\
\hline 32 & B9 & $\mathrm{G}+\mathrm{ve}$ & Rod & + & - & \\
\hline 33 & B10 & $\mathrm{G}+\mathrm{ve}$ & Rod & - & - & \\
\hline 34 & B11 & $\mathrm{G}+\mathrm{ve}$ & Rod & - & - & \\
\hline 35 & B12 & $\mathrm{G}+\mathrm{ve}$ & Rod & - & - & \\
\hline 36 & $\mathrm{C} 1$ & $\mathrm{G}+\mathrm{ve}$ & Rod & - & ++ & \multirow{27}{*}{ 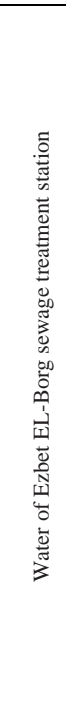 } \\
\hline 37 & $\mathrm{C} 2$ & $\mathrm{G}+\mathrm{ve}$ & Rod & + & - & \\
\hline 38 & C3 & G -ve & Rod & - & ++ & \\
\hline 39 & $\mathrm{C} 4$ & $\mathrm{G}+\mathrm{ve}$ & Rod & - & - & \\
\hline 40 & $\mathrm{C} 5$ & $\mathrm{G}+\mathrm{ve}$ & Rod & + & + & \\
\hline 41 & C6 & $\mathrm{G}+\mathrm{ve}$ & Rod & + & - & \\
\hline 42 & $\mathrm{C} 7$ & $\mathrm{G}+\mathrm{ve}$ & Rod & - & + & \\
\hline 43 & $\mathrm{C} 8$ & $\mathrm{G}+\mathrm{ve}$ & Rod & + & - & \\
\hline 44 & C9 & $\mathrm{G}+\mathrm{ve}$ & Rod & - & - & \\
\hline 45 & $\mathrm{C} 10$ & $\mathrm{G}+\mathrm{ve}$ & Rod & - & + & \\
\hline 46 & C11 & $\mathrm{G}+\mathrm{ve}$ & Rod & + & - & \\
\hline 47 & C12 & $\mathrm{G}+\mathrm{ve}$ & Rod & + & - & \\
\hline 48 & $\mathrm{C} 13$ & $\mathrm{G}+\mathrm{ve}$ & Rod & + & - & \\
\hline 49 & C14 & $\mathrm{G}+\mathrm{ve}$ & Rod & - & ++ & \\
\hline 50 & C15 & $\mathrm{G}+\mathrm{ve}$ & Rod & - & + & \\
\hline 51 & C16 & $\mathrm{G}+\mathrm{ve}$ & Cocci & - & +++ & \\
\hline 52 & C17 & G - ve & Rod & - & +++ & \\
\hline 53 & $\mathrm{C} 18$ & G -ve & Rod & - & - & \\
\hline 54 & C19 & $\mathrm{G}+\mathrm{ve}$ & Rod & + & - & \\
\hline 55 & C20 & $\mathrm{G}+\mathrm{ve}$ & Rod & + & + & \\
\hline 56 & C21 & $\mathrm{G}+\mathrm{ve}$ & Rod & + & - & \\
\hline 57 & $\mathrm{C} 22$ & $\mathrm{G}+\mathrm{ve}$ & Rod & - & - & \\
\hline 58 & $\mathrm{C} 23$ & $\mathrm{G}+\mathrm{ve}$ & Rod & - & - & \\
\hline 59 & C24 & $\mathrm{G}+\mathrm{ve}$ & Rod & - & - & \\
\hline 60 & $\mathrm{C} 25$ & $\mathrm{G}+\mathrm{ve}$ & Rod & - & - & \\
\hline 61 & C26 & $\mathrm{G}+\mathrm{ve}$ & Cocci & - & + & \\
\hline 62 & $\mathrm{C} 27$ & $\mathrm{G}+\mathrm{ve}$ & $\operatorname{Rod}$ & - & + & \\
\hline 63 & D1 & G -ve & Rod & 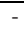 & - & \multirow{13}{*}{ 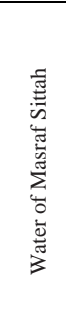 } \\
\hline 64 & D2 & G -ve & Rod & - & - & \\
\hline 65 & D3 & G -ve & Rod & - & ++ & \\
\hline 66 & D4 & G -ve & Rod & - & ++ & \\
\hline 67 & D5 & G -ve & Rod & - & - & \\
\hline 68 & D6 & G -ve & Rod & - & ++++ & \\
\hline 69 & D7 & G -ve & Rod & - & - & \\
\hline 70 & D8 & G -ve & Rod & - & ++++ & \\
\hline 71 & D9 & G -ve & Rod & - & +++ & \\
\hline 72 & D10 & G -ve & Rod & - & - & \\
\hline 73 & D11 & G -ve & Rod & - & ++++ & \\
\hline 74 & D12 & G -ve & Rod & - & + & \\
\hline 75 & D13 & G -ve & Rod & - & & \\
\hline
\end{tabular}

Symbols: -, negative; +, very weak; ++, weak; +++,

medium; ++++, high AgNPs biosynthesis.

Further, identification of the best AgNPs producer (D11 isolate) was performed using morphological characteristics as shown in Table 2 and molecular characterization. Interestingly, the isolate D11 showed clustering with different species of Enterobacter with 99.4-99.8 \% bootstrap value in phylogram (Figure 1).

\section{Characterization of silver nanoparticles}

The absorption peaks recorded in the range 370 $750 \mathrm{~nm}$ in the UV-vis spectra with the maximum peak at $477 \mathrm{~nm}$ (check??) further confirmed the formation of AgNPs as shown in Figure 2. TEM image confirmed spherical shaped, well-dispersed AgNPs with average size of 9.45-17.15 nm diameters (Figure 3a). Zeta potential measurement showed the negative charge of the nanoparticles (Figure $3 b$ ) and size distribution by volume showed in Figure 3c.

Table 2: Morphological characteristics for identification of bacterial isolate D11.

\begin{tabular}{|c|c|}
\hline $\begin{array}{l}\text { MICROSCOPIC } \\
\text { AND CULTURAL } \\
\text { CHARACTERS } \\
\end{array}$ & REACTIVITY \\
\hline Optimum temperature & $35^{\circ} \mathrm{C}$ \\
\hline Air condition & Facultative anaerobic \\
\hline Gram stain & Negative \\
\hline Shape & Rod \\
\hline Spore formation & Absence \\
\hline Pigmentation & Yellow pigment \\
\hline $\begin{array}{l}\text { Growth on isolation } \\
\text { medium }\end{array}$ & $\begin{array}{l}\text { Grow on nutrient agar medium, } \\
\text { circular white moist smooth } \\
\text { opaque colonies with entire } \\
\text { edge accompanying with } \\
\text { yellow pigment }\end{array}$ \\
\hline
\end{tabular}

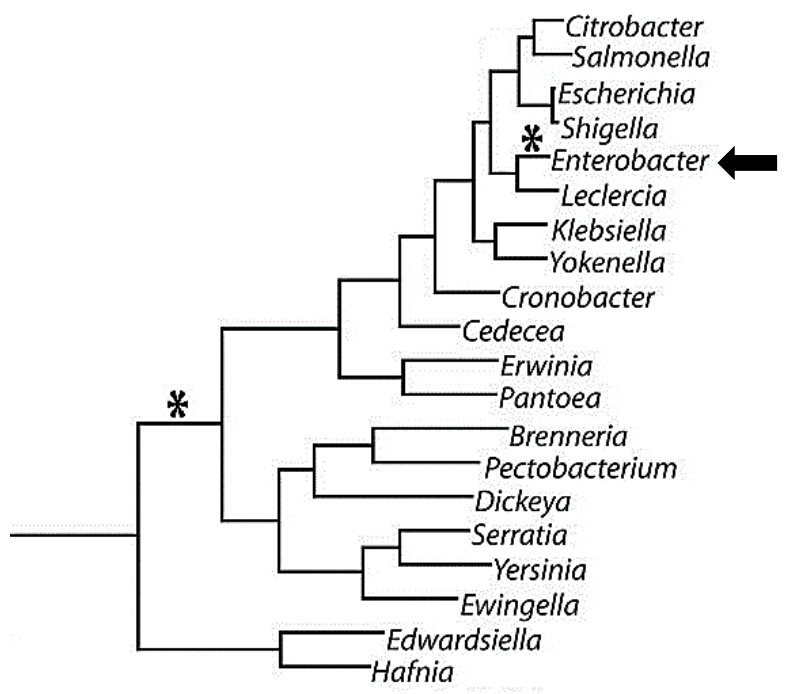

Figure 1. Phylogenetic tree analysis based on $16 \mathrm{~S}$ rDNA sequence alignment for Enterobacter sp. with some other related species, which possessed the highest similarity. The neighbour-joining was performed using the maximum composite likelihood methods (Tamura and Nei, 1993). 


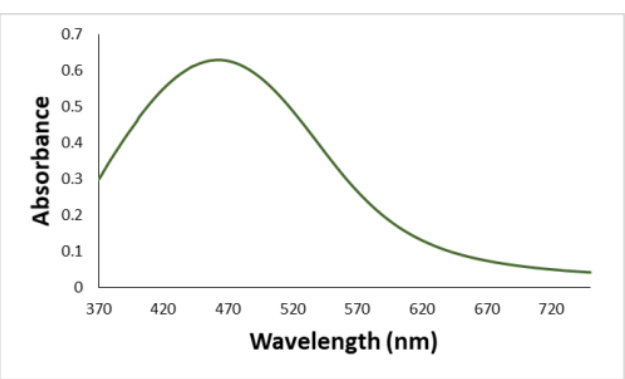

Figure 2. Silver nanoparticles synthesized using Enterobacter sp. bacterial supernatant. The tested production supported the nanoparticle synthesis as it can be seen from UV-vis spectra.

(a)

(b)

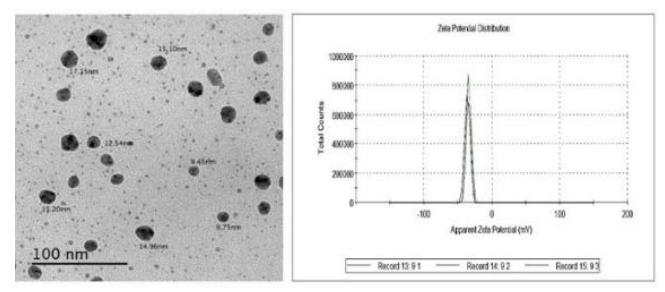

(c)

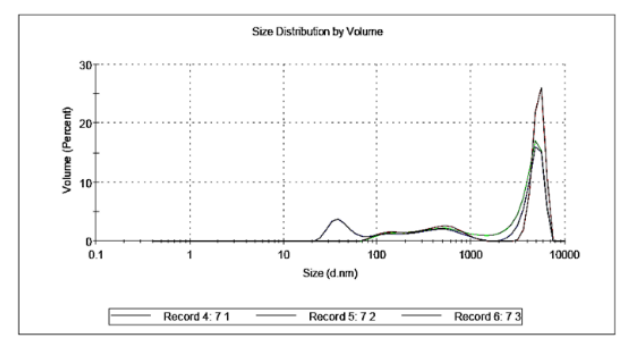

Figure 3. Characterization of silver nanoparticles synthesized using Enterobacter sp. supernatant. (a) Transmission electron microscopic image of spherical shaped silver nanoparticles. The size of the nanoparticles was $9.45-17.15 \mathrm{~nm}($ scale bar $=100 \mathrm{~nm})$. (b) Zeta potential measurement analysis of silver nanoparticles. (c) Size distribution by volume.

\section{Antifungal activity of AgNPs against Fusarium oxysporum f. sp. lycopersici}

AgNPs synthesized from Enterobacter sp. showed inhibitory activity against Fusarium oxysporum $\mathrm{f}$. sp. lycopersici and the data are presented Table 3 and Figures 4 and 5.

Table 3: Radial growth of Fusarium oxysporum f. sp. lycopersici mycelium ( $\mathrm{mm}$ )

\begin{tabular}{|c|c|c|c|c|c|}
\hline \multirow[b]{2}{*}{ Fungus } & \multicolumn{5}{|c|}{ Radial Growth of Fungal Mycelium (mm) } \\
\hline & $\begin{array}{l}\text { contr } \\
\text { ol }\end{array}$ & $\begin{array}{l}\mathrm{AgN} \\
\mathrm{Ps}\end{array}$ & $\begin{array}{l}\text { miconazo } \\
\text { le nitrate }\end{array}$ & $\begin{array}{l}\text { AgNPs + } \\
\text { miconazo } \\
\text { le nitrate }\end{array}$ & $\begin{array}{l}\mathrm{AgNO} \\
3 \\
\text { solutio } \\
\mathrm{n}\end{array}$ \\
\hline $\begin{array}{l}\text { Fusarium } \\
\text { oxysporu } \\
m \text { f. Sp. } \\
\text { Lycopers } \\
\text { ici }\end{array}$ & 100 & 51.88 & 44.25 & 61.03 & 79.17 \\
\hline
\end{tabular}

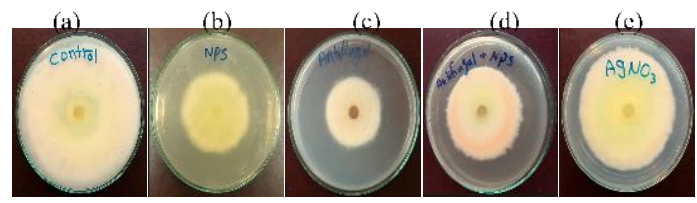

Figure 4: Radial growth of fungal mycelium that was recorded for tested fungus Fusarium oxysporum f. sp. lycopersici. (a) Control, (b) AgNPs, (c) miconazole nitrate, (d) AgNPs + miconazole nitrate, (e) silver nitrate solution.

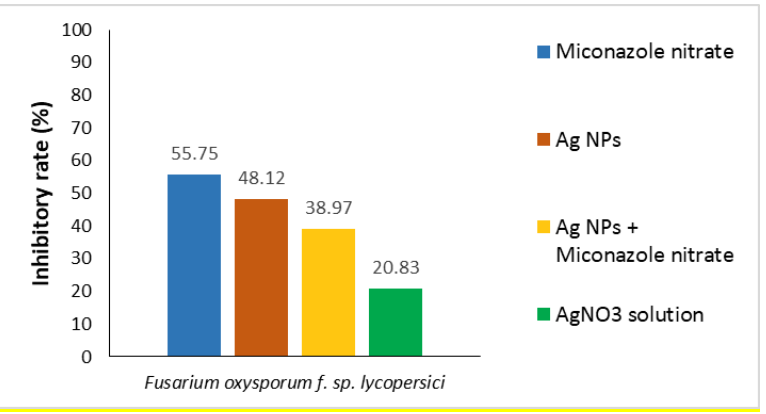

Figure 5: Inhibitory rate (\%) against Fusarium oxysporum f. sp. lycopersici.

\section{Discussion}

Water environment is considered as a reservoir of biological as well as chemical diversity. The present study was aimed to isolate water bacteria from different water sources in Damietta Governorate, Egypt with an ultimate objective to produce antifungal nanoparticles. The results showed that there were a synthesis of AgNPs differed from bacterial isolates. There are about three bacterial isolates had the best production rates among others. Only three isolates have synthesized extremely stable nanoparticles. The isolate designated as D11 produced the metal nanoparticles within $72 \mathrm{hrs}$ in dark conditions which was similar to the production using Bacillus flexus (Payal and Nikhilesh, 2017). Interestingly, the isolate D11 was identified as Enterobacter sp. The complete molecular studies together with classical taxonomy results strongly supported the identification of isolated strain as Enterobacter sp. In this study, based on the particle stability and faster rate of synthesis, Enterobacter sp. was recognized as a potential strain for the extracellular synthesis of silver nanoparticles.

The first indication for AgNPs biosynthesis is the color change. Brown color formed in the medium indicated the biosynthesis of AgNPs. The color change was due to the excitation of surface Plasmon vibrations, which is a characteristic feature of synthesized nanoparticles (Kalimuthu et al., 2008; Das et al., 2014). Enterobacter sp. 
produced spherical shaped, well-dispersed AgNPs, which similar to Bacillus sp. AgNPs extracellular biosynthesis by Vithiya et al. (2014) and Gopinath and Velusamy (2013) in case of Bacillus sp. GP-23 which produced spherical shaped AgNPs in addition to Acinetobacter baumannii (Shaker and Shaaban, 2017) and Leuconostoc lactis (Saravanan et al., 2017). The particle size distribution analysis revealed an average size of 9.45-17.15 nm diameter which matched with Balakumarana et al. (2016) who obtained AgNPs which have size ranged from 8$20 \mathrm{~nm}$. Zeta potential measurement confirmed the charge of the nanoparticles and it was found to be a negative for the metal nanoparticles. Much similar to our present study, Elbeshehy et al. (2015) have shown a negative zeta potential for Bacillus spp. that synthesized AgNPs. WrótniakDrzewiecka et al. (2014) found a surface zeta potential graph showing the negative zeta potential value for AgNPs synthesized by cell free extract of Myxococcus virescens and Boopathi et al. (2012) also showed a negative zeta potential for Pseudomonas aeruginosa M6 synthesized AgNPs. A common problem observed with nanoparticles production is aggregation, which greatly decreases the surface area of the nanoparticles and, in turn, affects their chemical, physical, and biological properties (Sintubin et al., 2012). To assess the stability of AgNPs formed in the medium, UV-vis spectrophotometric study was carried out. In case of silver nanoparticles, there was no alteration in the peak at $467 \mathrm{~nm}$ even after 2 months of incubation period. There was no sign of aggregation of nanoparticles observed (Balakumaran, 2016). The synthesized AgNPs from Bacillus spp. were found to be stable for up to $48 \mathrm{~h}$ (Elbeshehy et al., 2015). Thus, it is obvious from these observations that, the biosynthesized AgNPs are stabilized by the capping agent that is likely to be proteins present in the Enterobacter sp. supernatant.

AgNPs synthesized from Enterobacter sp. showed a potent antimicrobial activity against Fusarium oxysporum f. sp. lycopersici. AgNPs synthesized from Enterobacter sp. exhibited potent inhibitory activity with a clear inhibition rate (48.12\%). The synthesized AgNPs matched with significant antifungal activity against Fusarium oxysporum $\mathrm{f}$. sp. lycopersici by Dar et al. (2013) and Devi and Joshi (2012).

\section{Conclusions}

To our knowledge, this is the first study in which, AgNPs were synthesized using the bacterial supernatant of Enterobacter sp., isolated from water samples in Damietta Governorate. The biosynthesis protocol employed in the present study was found to be simple, rapid, costeffective, and ecofriendly. Thus, this extracellular synthesis method has huge potential to develop into the simple bioprocess system for sustainable production of nanoparticles at larger amount in addition to their high stability and a negative zeta potential. Moreover, the remarkable antimicrobial activity of AgNPs produced from Enterobacter sp. was detected against Fusarium oxysporum f. sp. lycopersici.

\section{Acknowledgment}

We would like to thank Dr. Ahmed K.A. ElSayed, Department of Botany and Microbiology, Faculty of Science, Damietta University, Egypt, who kindly performed the DNA extraction and sequence analysis. Also, thanks due to Prof. Amira El-Falal at the same Department for providing the plant pathogenic fungus Fusarium oxysporum $\mathrm{f}$. sp. lycopersici.

\section{References}

Abbaszadegan A, Ghahramani Y, Gholami A, Hemmateenejad B, Dorostkar S, Nabavizadeh M, Sharghi H, (2015) The effect of charge at the surface of silver nanoparticles on antimicrobial activity against gram-positive and gram-negative bacteria: a preliminary study. J. Nanomater., 2015: 1-8.

Ahmad A, Senapati S, Khan MI, Kumar R, Sastry M, (2005) Extra-intracellular biosynthesis of gold nanoparticles by an alkalotolerant fungus, Trichothecium sp. J. Biomed. Nanotechnol., 1: 4753.

Altschul SF, Gish W, Miller W, Myers EW, Lipman DJ, (1990) Basic local alignment search tool. J. Mol. Biol. Med., 215: 403-410.

Altschul SF, Madden TL, Schaffer AA, Zhang J, Zhang Z, Miller W, (1997) Gapped BLAST and PSIBLAST: A new generation of protein database search programs. Nucleic Acids Res., 25: 33893402.

Ausubel FM, Brent R, Kingston RE, Moore DD, Seidman JG, Smith JA, Struhl K (editors), (2003) Current protocols in molecular biology. Suppl. 59, 
unit 2.1A, John Wiley \& Sons Inc; ringbou edition, p 206.

Balakumarana MD, Ramachandrana R, Balashanmugama P, Mukeshkumarb DJ, Kalaichelvana PT, (2016) Mycosynthesis of silver and gold nanoparticles: Optimization, characterization and antimicrobial activity against human pathogens. Microbiol. Res., 182: 8-20.

Boisselier E, Astruc D, (2009) Gold nanoparticles in nanomedicine: preparations, imaging, diagnostics, therapies and toxicity. Chem. Soc. Rev., 38: 17591782.

Boopathi S, Gopinath S, Boopathi T, Balamurugan V, Rajeshkumar R, Sundararaman M, (2012) Characterization and antimicrobial properties of silver and silver oxide nanoparticles synthesized by cell-free extract of a mangrove-associated Pseudomonas aeruginosa M6 using two different thermal treatments. Ind. Eng. Chem. Res., 51: 59765985.

Chou KS, Lu YC, Lee HH, (2005) Effect of alkaline ion on the mechanism and kinetics of chemical reduction of silver. Mater. Chem. Phys., 94: 429433.

Dar MA, Ingle A, Rai M, (2013) Enhanced antimicrobial activity of silver nanoparticles synthesized by Cryphonectria sp. evaluated singly and in combination with antibiotics. Nanomed. Nanotechnol. J., 9: 105-110.

Das V, Thomas R, Varghese R, Soniya EV, Mathew J, (2014) Extracellular synthesis of silver nanoparticles by the Bacillus strain CS 11 isolated from industrialized area. Biotechnology, 45: 12211227.

Devi JS, Bhimba BV, (2014) Antibacterial and antifungal activity of silver nanoparticles synthesized using hypnea muciformis. Biosci. Biotechnol. Res. Asia, 11: 235-238.

Devi LS, Joshi SR, (2012) Antimicrobial and synergistic effects of silver nanoparticles synthesized using soil fungi of high altitudes of Eastern Himalaya. Mycobiology, 40: 27-34.

Elbeshehy EKF, Elazzazy AM, Aggelis G, (2015) Silver nanoparticles synthesis mediated by new isolates of Bacillus spp., nanoparticle characterization and their activity against bean yellow mosaic virus and human pathogens. Front. Microbiol., 6: 453.

Garrity G, Staley JT, Boone DR, De Vos P, Goodfellow M, Rainey FA, Schleifer KH, Brenner DJ (Ed.), Krieg NR (Ed.), (2006) Bergey's manual® of systematic bacteriology: Volume two: The proteobacteria. Springer science \& business Med. Springer-Verlag, New York, USA, 1206-1208.

Gopinath V, Velusamy P, (2013) Extracellular biosynthesis of silver nanoparticles using Bacillus sp. GP-23 and evaluation of their antifungal activity towards Fusarium oxysporum. Spectrochim. Acta
A Mol. Biomol. Spectrosc., 10: 170-174.

Hanaor D, Michelazzi M, Leonelli C, Sorrell CC, (2012) The effects of carboxylic acids on the aqueous dispersion and electrophoretic deposition of ZrO2. J. Am. Ceram., Soc., 32: 235-244.

He S, Guo Z, Zhang Y, Zhang S, Wang J, Gu N, (2007) Biosynthesis of gold nanoparticles using the bacteria Rhodopseudomonas capsulata. Mater. Lett., 61: 3984-3987.

Jiang H, Dong H, Zhang G, Yu B, Chapman LR, Fields MW, (2006) Microbial diversity in water and sediment of Lake Chaka, an athalassohaline lake in northwestern China. Appl. Environ. Microbiol., 72: 3832-3845.

Kafshgari MH, Voelcker NH, Harding FJ, (2015) Applications of zero-valent silicon nanostructures in biomedicine. Nanomedicine, 10: 2553-2571.

Kalimuthu K, Babu RS, Venkataraman D, Bilal M, Gurunathan S, (2008) Biosynthesis of silver nanocrystals by Bacillus licheniformis. Colloids Surf. B Biointerfaces, 65: 150-153.

Krishnaraj C, Ramachandran R, Mohan K, Kalaichelvan PT, (2012) Optimization for rapid synthesis of silver nanoparticles and its effect on phytopathogenic fungi. Spectrochim Acta A Mol. Biomol. Spectrosc., 93: 95-99.

Lengke M, Southam G, (2006) Bioaccumulation of gold by sulfate-reducing bacteria cultured in the presence of gold (I)-thiosulfate complex. Geochim. Cosmochim. Acta, 70: 3646-3661.

Matsumura Y, Yoshikata K, Kunisaki SI, Tsuchido T, (2003) Mode of bactericidal action of silver zeolite and its comparison with that of silver nitrate. Appl. Environ. Microbiol., 69: 74278-74281.

Morais MG, Martins VG, Steffens D, Pranke P, Costa JAV, (2014) Biological applications of nanobiotechnology. J. Nanosci. Nanotechnol., 14: 1007-1017.

Parikh RY, Singh S, Prasad BLV, Patole MS, Sastry M, (2008) Extracellular Synthesis of crystalline silver nanoparticles and molecular evidence of silver resistance from Morganella sp.: towards understanding biochemical synthesis mechanism. Chembiochem., 9: 1415-1422.

Payal NA, Nikhilesh SK, (2017) Biosynthesis of silver nanoparticles from silver resistance bacteria isolated from metal contaminated soil. SAJB, 5: 187-191.

Saravanan C, Rajesh R, Kaviarasan T, Muthukumar K, Kavitake D, Shetty PH, (2017) Synthesis of silver nanoparticles using bacterial exopolysaccharide and its application for degradation of azo-dyes. Biotechnol Rep. s--rr: 10 6.

Sathishkumar M, Sneha K, Yun YS, (2010) Immobilization of silver nanoparticles synthesized using Curcuma longa tuber powder and extract on cotton cloth for bactericidal activity. Biores. 
Technol., 101:7958-7965.

Shahverdi AR, Minaeian S, Shahverdi HR, Jamalifar H, Nohi AA, (2007) Rapid synthesis of silver nanoparticles using culture supernatants of Enterobacteria: a novel biological approach. Process Biochem., 42: 919-923.

Shaker MA, Shaaban MI, (2017) Synthesis of silver nanoparticles with antimicrobial and anti-adherence activities against multidrug-resistant isolates from Acinetobacter baumannii. J Taibah Univ Sci., 2017: 1-7.

Shanmugaiah V, Harikrishnan H, Al-Harbi NS, Shine K, Khaled JM, Balasubramanian N, Kumar RS, (2015) Facile synthesis of silver nanoparticles using Streptomyces sp.VSMGT1014 and their antimicrobial efficiency. Dig. J. Nanomater. Bios., 10: $179-187$.

Sharma RK, Gulati S, Mehta S, (2012) Preparation of gold nanoparticles using tea: a green chemistry experiment J. Chem. Educ., 89: 1316-1318.

Sievers F, Wilm A, Dineen D, Gibson TJ, Karplus K, Li W, Thompson JD, (2011) Fast, scalable generation of high-quality protein multiple sequence alignments using Clustal Omega. Mol. Syst. Biol., 7: 539.

Sintubin L, De Windt W, Dick J, Mast J, van der Ha D, (2009) Lactic acid bacteria as reducing and capping agent for the fast and efficient production of silver nanoparticles. Appl. Microbiol. Biotechnol., 84: 741-749.

Sintubin L, Verstraete W, Boon N, (2012) Biologically produced nanosilver: current state and future perspectives. Biotechnol. Bioeng., 109: 2422-2436.

Tamura K, Dudley J, Nei M, Kumar S, (2007) MEGA4: molecular evolutionary genetics analysis (MEGA) software version 4.0. Mol. Biol. Evol., 24: 15961599.

Tamura K, Nei M, (1993) Estimation of the number of nucleotide substitutions in the control region of mitochondrial DNA in humans and chimpanzees. Mol. Biol. Evol., 10: 512-526.

Vithiya K, Kumar R, Sen S, (2014) Bacillus sp. mediated extracellular synthesis of silvernano. Int. J. Pharm. Pharm. Sci., 6: 525-527.

Wang ZL, (2000) Transmission electron microscopy of shape-controlled nanocrystals and their assemblies. J. Phys. Chem. B, 104: 1153-1175.

Wrótniak-Drzewiecka W, Gaikwad S, Laskowski D, Dahm H, Niedojadło J, Gade A, Rai M, (2014) Novel approach towards synthesis of silver nanoparticles from Myxococcus virescens and their lethality on pathogenic bacterial cells. Austin J. Biotechnol. Bioeng., 1: 1-7.

\title{
عنوان البحث: تخليق جسيمات الفضة النانوية بواسطة بكتريا انتيروباكتر و دراسة قرتها التضادية لفطر

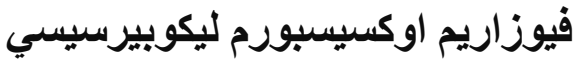 \\ محمد مرزوق الزاهد'“، محمود متولي نور الدين'، محمد اسماعيل أبو دبارة'، زكريا عوض محمد بقا' ' قسم النبات والميكروبيولوجي ـ كلية العلوم - جامعة دمياط
}

\begin{abstract}
تم أخذ عينات مياه من مناطق مختلفة بمحافظة دمياط (مثل مجرى نهر النيل برأس البر- محطة الصرف الصحي بمدينة عزبة

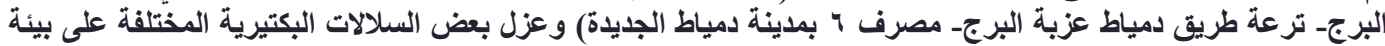

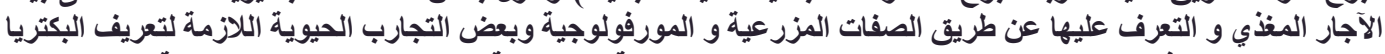

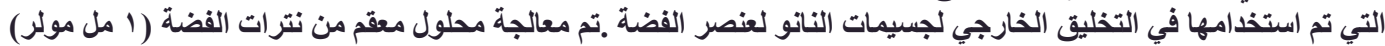

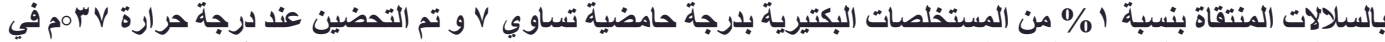

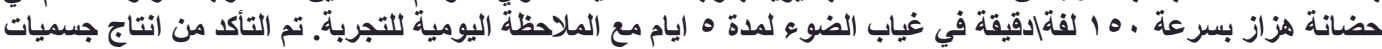

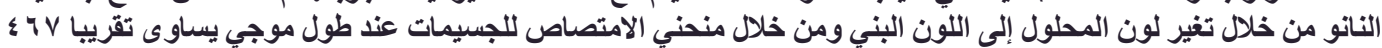

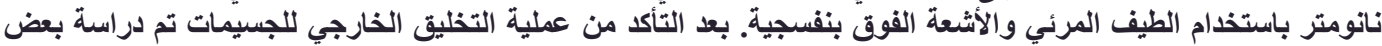

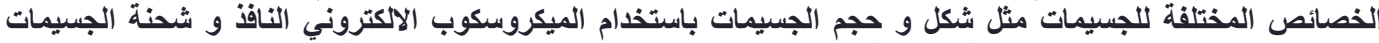

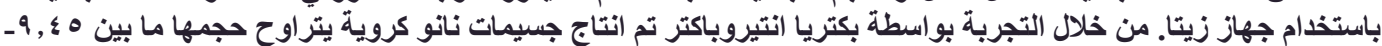

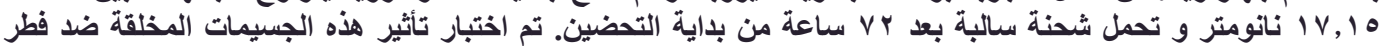

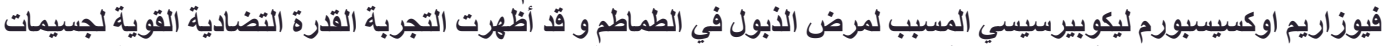

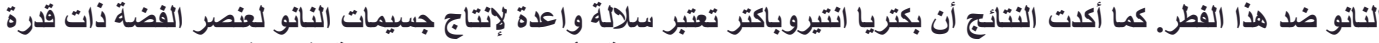

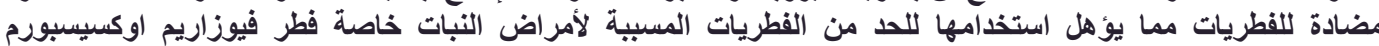

